\title{
Rebellion or riot?: black Loyalist food laws in Sierra Leone
}

\section{Rachel B. Herrmann}

To cite this article: Rachel B. Herrmann (2016) Rebellion or riot?: black Loyalist food laws in Sierra Leone, Slavery \& Abolition, 37:4, 680-703, DOI: 10.1080/0144039X.2016.1150686

To link to this article: https://doi.org/10.1080/0144039X.2016.1150686

册 Published online: 10 Mar 2016.

Submit your article to this journal 지

Џll Article views: 623

View Crossmark data \lceil 


\title{
Rebellion or riot?: black Loyalist food laws in Sierra Leone
}

\author{
Rachel B. Herrmann
}

\begin{abstract}
In 1800 black Loyalists in Sierra Leone participated in an event that historians have called a rebellion. Reinterpreting the 1800 rebellion as a food riot reveals more extensive black Loyalist political activity in the 1790s, greater cooperation between black Loyalists and white councilmen, and increased animosity between black Loyalists and Africans. Black Loyalists created food legislation with the approval of the Sierra Leone Council, but those laws fostered disagreements with Africans. When the Sierra Leone Council revoked the black Loyalists' law-making abilities, colonists rioted to reclaim the political and legal rights that they developed through their food legislation.
\end{abstract}

In September 1800, elected black Loyalists in Freetown, Sierra Leone posted laws that fixed butter, cheese, salt beef, salt pork, rice, rum, and sugar prices. By December, these men had been banished, bayonetted, sentenced to hard labour, or hanged. The laws declared that anyone who refused to sell foodstuffs to other black Loyalists and who was then 'found carrying' such commodities 'out of the Colony' would incur a fine. The code of laws also delineated punishments for adultery, stealing, and Sabbath-breaking, denied the white governor and Sierra Leone Council the authority to interfere in domestic affairs, and warned that black Loyalists had to abide by the document or leave Freetown. When Governor Thomas Ludlum learned of these laws, he accused the elected men of rebellion. He armed company employees and trusted blacks to pursue the so-called rebels. After a week-long standoff, a ship arrived carrying British soldiers and Jamaican Maroons, who captured enough black Loyalists to procure peace in October. ${ }^{1}$ By December, armed with a new royal charter, the Sierra Leone Council convened a military tribunal, meted out punishment, and revoked all blacks' rights to elect representatives. ${ }^{2}$

Black Loyalists, in fixing prices and preventing foodstuffs from leaving the colony, demanded political rights by behaving like food rioters. Yet white officials called this event a 'rebellion' - as have most historians. This essay makes two contributions. First, it examines the 1800 event within the context of food 
riots to question the appropriateness of the term 'rebellion'. Second, it argues that regardless of what one calls the occurrence, black Loyalists' food legislation leading up to the event reveals more extensive political activity, greater cooperation between black Loyalists and white councilmen, and a higher degree of animosity between black Loyalists and Africans than scholars have supposed.

The history of Freetown's black colonists - known interchangeably as 'black Loyalists' and 'Nova Scotians' - fits into three categories. ${ }^{3}$ The first works survey these former slaves' flight to the British during the American Revolution, and their subsequent migration to Nova Scotia and Sierra Leone. They focus on land problems and disagreements with white governing officials. ${ }^{4}$ Second are studies that compare Freetown to other colonisation efforts. ${ }^{5}$ Third are works on diaspora, migration, and the Revolutionary Atlantic. ${ }^{6}$ In these interpretations, the elected black Loyalists, known as Hundredors and Tythingmen, tend to disappear between 1792 and 1798, and most discussions concern their demands for land. A few works have interpreted the Hundredors' and Tythingmens' laws, but pushed their occurrence to 1795, or treated them as a domestic issue. ${ }^{7}$ Historians have portrayed the 1800 'rebellion' as the climax of conflict over land, and as a definitive break between the Sierra Leone Council and black Loyalists. Only Cassandra Pybus has questioned whether the 1800 occurrence was a rebellion. ${ }^{8}$

A study of food laws uncovers the white council's willingness to cooperate with black Loyalists, a shift in black Loyalists' relationships with Africans from peaceful encounters to violence, and similarities between the Freetown protest and other food riots. No scholar has situated the 1800 event within the context of black Loyalists' relations with the Temne, though James Sidbury has explored these interactions more generally. ${ }^{9}$ Little work exists on food in the early years of the colony, and what does emphasises the Sierra Leone Company's interest in cash crops for legitimate commerce, or white colonists' interactions with the Temne. ${ }^{10}$ It was likely Temne reactions to black Loyalists' food laws that encouraged white councilmen to curtail black Loyalist law-making just before 1800. Black Loyalists' efforts to regain this right culminated in protest. Especially in the eighteenth century, food rioters fell back on their right to crowd action when government failed them. Colonists in Freetown acted like other rioters, but the fact that they passed their own laws to prevent scarcity before the riot also sets them apart. The history of food thus presents an opportunity for historians to consider an understudied form of political activity among recently emancipated peoples.

This history begins in 1782, when escaped slaves who had run to the British during the War for Independence fled the United States. By 1783, nearly 3000 formerly enslaved men and women had arrived in Nova Scotia. ${ }^{11}$ In the late 1780s, British failures to apportion land motivated discontented black colonists to leave Nova Scotia. ${ }^{12}$ Simultaneously, a group of British abolitionists 
confronted several failed experiments on the upper Guinea coast: the province of Senegambia, the colony of Bulama, and the first Granville Town colony of London's Black Poor. ${ }^{13}$ In 1791, Thomas Clarkson, his younger brother John, Granville Sharp, Henry Thornton, and William Wilberforce formed the Sierra Leone Company to supervise an antislavery colony in Africa. When one black colonist named Thomas Peters sailed from Nova Scotia to London to petition these men for a better life, he convinced them that his fellow colonists would make ideal migrants. ${ }^{14}$

Over 1000 blacks, led by the Reverend John Clarkson, sailed from the Maritimes to Sierra Leone in January 1792, arrived in March, and renamed Granville Town Free Town - which became Freetown. ${ }^{15}$ Although colonists sometimes clashed with Clarkson, his governorship was characterised more by accommodation than by conflict. During the mid-1790s these former slaves, who now called themselves Nova Scotians, created food laws that the Sierra Leone Council regularly approved. By the late 1790s, worsening relations with the Susu and Temne prompted a change in the council's enthusiasm for black Loyalist law-making. The Nova Scotians began to lose control of their legislative rights, and protested to reclaim them in September 1800.

Whereas early studies of marketplace regulation attributed outbreaks of food riots to mere hunger, more recent scholarship has traced the political, organised nature of such events. ${ }^{16}$ Numerous historians have described how the Nova Scotians 'rebelled' in 1800, but the records of the event reveal similarities with other political food protests. According to the council, on 10 September elected leaders Isaac Anderson, James Robertson, Nathaniel Wansey, and Ansel Zizer revealed their code of laws - which fixed prices for foodstuffs - at the house of Abraham Smith. These men encouraged others to join them, reposting a revised code on the $25^{\text {th }} \cdot{ }^{17}$ Governor Thomas Ludlum armed company employees and nonriotous black Loyalists, and sent them after the 'rebels', which precipitated a scuffle. Robertson was captured, Zizer surrendered, and Anderson and Wansey (though stabbed with a bayonet) escaped to rally about 50 of the 300 colonists. By the 27th, 'intelligence was received that the Hundredors \& Tythingmen ... were in a state of open rebellion'. Posted at a bridge, they 'cut off all communication between Freetown \& the Country... and were receiving hourly supplies of men \& provisions from both'. They stole one gun, and shot, powder, money, mats, hides, liquor, sugar, tea, and clothing from council members' houses. ${ }^{18}$ A Temne subruler named King Tom, also known as $\mathrm{Pa}$ Kokelly, may have suggested that he would become involved. ${ }^{19}$ And then the British ship the Asia arrived carrying 45 British soldiers, and Jamaican Maroons from Nova Scotia. They forced a peace with the black Loyalists in October. $^{20}$

On the one hand, it could be argued that the event was a rebellion. Historians have interpreted it as the culmination of a fight - evident throughout the 1790s in disagreements over a quitrent tax - over land. ${ }^{21}$ They have chronicled white 
leaders' disapproval of many of the black Loyalists who won office in the 1798 elections. $^{22}$ The black Loyalists were armed, and they pilfered from the houses of white councilmen. King Tom's willingness to lend support implies black Loyalist-Temne cooperation rather than friction. The council suggested that many colonists disapproved of fellow black Loyalists' actions by recording the 'general indignation at the power assumed by the Hundredors and Tythingmen in pretending to bind them by new laws'. ${ }^{23}$ In executing and banishing the Loyalists, and in the language used in post-September accounts, the white council treated the event as a rebellion. ${ }^{24}$

The terminology related to riot and rebellion is hardly uniform in scholarship. The literature on black rebellions is vast. ${ }^{25}$ Paul Gilje excludes slave rebellions from his survey of American riots because he argues that it was difficult for the enslaved to riot. $^{26}$ In some works, only after emancipation does crowd action become 'political unrest' or 'riot'. ${ }^{27}$ Other scholars, by contrast, have used terms like 'rebellion', 'riot', and 'uprising' interchangeably regardless of whether dissenters were enslaved or free. ${ }^{28}$ It must also be admitted that eighteenth-century people did not always distinguish between riot and rebellion.

Yet the actions of the black Loyalists, the delay between land fights and the 1800 event, a real rebellion close to Freetown, and the biases of the Sierra Leone Company and Council should make historians pause before calling the 1800 event a rebellion. The black Loyalists did not behave like rebels. They attacked no towns, burned no farm buildings or plantations, and killed, decapitated, and maimed no whites. ${ }^{29}$ The men were armed, but it is unclear how many guns they possessed, and whether the middle-aged rioters could commit violence. $^{30}$ The elections took place in 1798 and the council resolved to abolish the quitrent in 1799, meaning that colonists - who were allowed into office would have waited almost a year to rebel over land or political issues that had seemingly been resolved. ${ }^{31}$ Although the authors of the code did not obtain unanimous support, it seems odd that colonists would object to the idea of the code of laws because lawmakers had been legislating for eight years. With respect to King Tom, descriptions vary of his willingness to intervene - some historians say he implied his support, others that he stated it, and others that support was merely rumoured. ${ }^{32}$ The Sierra Leone Council claimed that intelligence was received' that the colonists obtained assistance from the interior, but did not state who supplied the information. ${ }^{33}$ An 1802 Sierra Leone Company report described how 'One or Two of the more unprincipled Chiefs, had been courted' by the Nova Scotians, 'with the View of effecting the Overthrow of the European Influence in the Colony. ${ }^{34}$ In 1801 and 1802 King Tom, with the approval of Bai Farma - the top ruler in the region - had led attacks on Freetown with the support of former black Loyalists. ${ }^{35}$ But even had the colonists cultivated those relationships by 1802, it is unclear whether King Tom's presence in the colony was imminent in 1800 . Nearby events in the years before the Loyalists' arrival were perhaps more appropriately dubbed rebellions. Between 1783 
and 1796 a slave uprising of Temne, Baga, and Bullom people had occurred in the Mandingo and Muslim state of Moria, to the north of Freetown. ${ }^{36}$ Those rebels had set fire to crops. ${ }^{37}$ Finally, to call the event a rebellion is to replicate the language of the white councilmen, who may have obscured details. The 1802 report stated its intention to explain the Sierra Leone Company's failures, and the council and company needed a scapegoat to avoid blaming themselves. ${ }^{38}$

Although the word 'riot' carries problematic connotations today, understanding food riots on their own terms makes apparent similarities between food riots and the Freetown event. During the 'golden age' of food riots between 1550 and 1820, two thirds of all riots in England related to food. Between 1776 and 1779, protesting crowds in America gathered on more than 30 different instances. ${ }^{39}$ In his case studies of eighteenth-century English riots, John Bohstedt argues that price-fixing was the most noticeable unifying factor, constituting 35 per cent of riotous behaviour between 1782 and 1812. There was a spate of food riots occurring at the exact same time as the one in Freetown - 154 from 18001801. As in Sierra Leone, many began in September of $1800 .^{40}$

The 1800 protest fits into patterns of riotous behaviour - the entrave or blockage; the agrarian demonstration; the price riot or taxation populaire; and the market riot. In the entrave, people prevented the export of grain from a rural area, whereas in an agrarian demonstration farmers destroyed their produce before it could depart. In the price riot, people seized food, set what they deemed a 'just' price, and sold it. In a market riot, urban crowds acted against local magistrates, commercial bakers, butchers, or millers to force a price reduction. ${ }^{41}$ Nova Scotians tried to prevent food from leaving Freetown, as in the entrave, they set prices, as in the price riot, and they criticised government officials, as in the market riot.

But the Nova Scotians' actions also transcend the categories of food riots. The commodities the rioters targeted, the composition of participants, and the punishments they incurred make Freetown different. Nova Scotians, like Europeans, tried to regulate prices for staple commodities, but they also policed meat, alcohol, and butter consumption, and in this instance, they did not try to fix bread or flour prices. In many riots, women started things because they remained unlikely to face capital punishment. ${ }^{42}$ Women in Freetown did not appear as rioters, but riot leaders did request protection for their women and children. ${ }^{43}$ Most food riots were leaderless, and carried out without arms. ${ }^{44}$ At least according to the council, the Sierra Leone riot had leaders, some of whom possessed arms. The riot also differed from England in the severity of its repercussions - death rates were higher in Freetown. ${ }^{45}$

Perhaps the 1800 conflict was a rebellion; perhaps it was a food riot; perhaps it was a rebellion with the characteristics of a food riot. Whichever way historians choose to describe it, food clearly mattered more to participants than scholars have previously acknowledged. A different line of inquiry, consequently, asks how and why ideas about food came to feature in black Loyalists' sense of 
their political and legal rights. The Nova Scotians were different because they acted in 1800, not to force the government to fix food prices, but to reclaim their right to do so. Other food riots began when officials could not protect the rights of ordinary people. In Sierra Leone, ordinary people and officials shared a responsibility to prevent hunger. Examining black Loyalists' food laws reveals the longer history of blacks' cooperation with the white council, and growing conflict with Africans.

The black Loyalists had been the ones instituting regulations early on in their chaotic first years. Colonists' efforts to prevent hunger - first, through negotiation with John Clarkson during his governorship, and then in the mid1790s through food legislation - allowed them to expand their rights. After the black Loyalists arrived in 1792, they hungered at regular times each year. During the rainy season from May until October, it became tricky to produce crops and shelter animals. ${ }^{46}$ Unstable relations with Africans, council corruption, and storage issues resulted in additional provisioning problems.

By the eighteenth century the upper Guinea coast was populated by Limba, Bullom, Temne, Baga, Loko, Susu, Mandingo, Koranko, and Fula peoples. ${ }^{47}$ Beginning in 1727 the Fula extended their dominance from Fouta Djallon coastward, subjecting the peoples of the Nunez River and the Susu of the Pongo River to a tributary alliance. ${ }^{48}$ This expansion was driven by a jihād, which began as a reaction against the slave trade and an attempt to spread Islam, but gradually became bound up in the economies and politics of slavery. ${ }^{49}$ Mande and Fula marabouts, or learned men, also spread Islam peacefully throughout Sierra Leone. ${ }^{50}$ By 1792 Freetown's colonists interacted most frequently with the Temne. The Koya Temne lived along the coast of Freetown and further inland, where they ran into the Masimera Temne. To the north of the Masimera were the Marampa Temne, and to the south were the Yoni Temne. Many Susu intermarried with the Temne, and settled peacefully among them as well as at Sendugu. Among the Temne, the Bai Farma was the top ruler, and was seated at Robaga. The Naimbana, whom the British called King Naimbana, ruled from Robana, and was next in the hierarchy. ${ }^{51}$ The Sierra Leone Council obtained land from him, which Naimbana viewed as a rental, but which Sierra Leone councilmen believed was a permanent purchase. ${ }^{52}$ Territorial disagreements persisted into the 1800 s. $^{53}$

The colony's all-white council not only struggled with the Temne, but also fought amongst themselves. Alexander Falconbridge, a slave ship surgeon turned abolitionist, complained that the Sierra Leone Company chose John Clarkson over him as superintendent. Falconbridge likely died of alcoholism. ${ }^{54}$ Other councilmen allowed themselves extra food and liquor while the rest of the colonists ate reduced rations, and sold ship's stores to Africans instead of distributing them. ${ }^{55}$ As superintendent, John Clarkson possessed insufficient authority. ${ }^{56}$ Only in mid-1792 did he convince the Sierra Leone Company to name him governor. 
When corrupt officials could procure food, they possessed no place to put it. Ships struggled to land on the rocky shore. ${ }^{57}$ When American vessels provided beef, molasses, and pork, the casks washed away in the tide. ${ }^{58}$ John Clarkson complained that careless storage of 'damaged cheese and biscuits, with other articles in a state of putrefaction' created 'a stench' around the shoddily built storehouse that mingled with the slurry of rot 'allowed to lie and soak into the ground'. By March 1792 provisions were slim, and by April colonists began eating half rations. In May, Clarkson, with dismay, reported people 'dying for want of food'. 59

Much about colonists' consumption habits remains unknown. As Philip Misevich points out, it has been possible to track ships' departures and arrivals in Freetown, but precise data on cargoes of incoming vessels is rather less specific'. ${ }^{60}$ From 1792 to 1801, the Sierra Leone Company sent at least 67 ships to obtain produce along the coast, and between 1795 and 1801 at least 10 vessels brought produce into Freetown, but over half of the outgoing voyages took place early on, in $1793 .{ }^{61}$ The French assaulted Freetown in September 1794 (a result of the French Revolutionary Wars), uprooted crops, killed one person, and wounded four. ${ }^{62}$ During the attack the Bai Farma captured several colony ships, which further impeded oceangoing capabilities. ${ }^{63}$ Fishing may have become dangerous after the French attack. Freetown's officials, by taking an antislavery stance and harbouring runaways, also risked conflict with the African headmen who supplied the colony with food. ${ }^{64}$

Colonists traded with Africans through coastal, riverine, and overland routes. The caravan trade linked to the interior brought cattle, gold, ivory, and slaves to the coast; the trade on the coast exchanged salt and kola nuts for meat and interior trade goods; and the one across the ocean required enslaved African bodies in exchange for guns and manufactures. ${ }^{65}$ The landlord-stranger relationship undergirded trade in the region. Landlords were African elites, and strangers were European, Euro-African, or African foreign residents. ${ }^{66}$ Landlords lodged and fed caravans, served as brokers, and provided commercial information and credit. ${ }^{67}$ Trade alliances were bound up in other networks of kinship, age groups, royal redistribution circuits, and secret societies (or power associations; the Poro for men, and the Sande for women), which the Fula established in Temne territory. ${ }^{68}$ The Sierra Leone Company had, since 1791 , tried to enter the currents of riverine trade, which supplied goods to the Nunez and Pongo traders. This strategy took two approaches: officials tried to open negotiations with the Fula in Fouta Djallon to get them to divert commerce from the Pongo and Nunez to Freetown, and they tried to set up trading settlements at caravan terminals and manipulate prices, which would give them control of legitimate commerce. ${ }^{69}$

These trade networks yielded various provisions from the Africans who remained in control. Crucial upland variety rice came via merchants from the Sherbro and Fouta Djalon, kola nuts from between Cape Mount and the 
Sierra Leone estuary, and salt from tide pools in the region north of Freetown. ${ }^{70}$ The Bullom Shore, on the northern estuary of the Sierra Leone River, provided rice and sugar for a limited time, before a wage disagreement between the Sierra Leone Council and the Bullom ended the arrangement. ${ }^{71}$ By October 1792, as many as 150 people 'of the Timmany nation' came daily bearing bananas, cassava, limes, oranges, pineapples, and plantains. ${ }^{72}$ 'Timmanies, Bullams, [and] Mandingoes' also provided rice, yams, and livestock. ${ }^{73}$

In addition to obtaining food from Africans, colonists avoided scarcity by consuming Sierra Leone Company rations and eventually, growing produce. The Sierra Leone Company had planned for colonists to receive 'full Provisions for three, and half Provisions for three other Months' ${ }^{74}$ During the colony's first two and a half years, the Sierra Leone Company spent $£ 20,000$ on provisions. $^{75}$ Although it is difficult to find statistics on black Loyalists' rations, partial data can be compared to other contemporary figures (Table 1).

Consumption changed with the weather. Mid-rainy season, in August 1793, Zachary Macaulay said that colonists could consume half a ton of rice per day. ${ }^{76}$ By September, when the population stood at 1052 (995 blacks and 57 whites), he thought slightly more than a third of a ton of rice was eaten daily. Using the high estimate, the population would have eaten .95 pounds of rice per day; using the low estimate they would have consumed two thirds of a pound. ${ }^{77}$ This quantity of rice was commensurate with rations for British soldiers, and the Maroons who arrived from Nova Scotia in 1800, suggesting that additional similarities existed in the quantities of meat, flour, and alcohol that black Loyalists received. From the Maroons' rations, one could guess that black Loyalist children received no meat in their ration despite the fact that the Company had originally planned that they would. When rations were reduced, meat supplies decreased, and men lost their flour, but women and children retained it. Once the 1792 rainy season passed, the surviving colonists grew and stored beans, cabbages, cassava, cresses, ground nuts, maize, pumpkins, purslane, rice, tropical fruits, sweet potatoes, and yams. They raised fowls and hogs, and hung 'beef and pork' for smoking. John Clarkson described their craze 'for building boats', and intention to fish. ${ }^{78}$

During Clarkson's governorship, in addition to these strategies for avoiding hunger, the black Loyalists regulated the sale and distribution of foodstuffs. These efforts broadened blacks' political participation by turning disagreements over food into colony-wide regulations. In August 1792, Nova Scotians petitioned John Clarkson and complained 'of the extravagant charge made by the fishermen'. Clarkson solved the problem by meeting with one Robert Horton, making him promise to lower prices, and to sell fish within the Colony 'before he offered them for sale to other people'. 79

Clarkson demonstrated a willingness to address black Loyalists' complaints by instituting fixed prices, but he decried the Sierra Leone Company's rationing. He argued that 'vice... wickedness and discontent' prevailed in the colony 
Table 1. Comparison of weekly rations. ${ }^{a}$

\begin{tabular}{|c|c|c|c|c|c|c|c|c|c|c|c|c|c|c|c|}
\hline & \multicolumn{5}{|c|}{ British military c. 1770 s } & \multicolumn{2}{|c|}{$\begin{array}{l}\text { Estimated rations for Maroons before } \\
\qquad 1800 \text { arrival }\end{array}$} & \multicolumn{4}{|c|}{ Maroons' rations April 1801} & \multicolumn{4}{|c|}{ Maroons' rations August 1801} \\
\hline & Beef or pork & Bread or flour & $\begin{array}{l}\text { Butter or } \\
\text { cheese }\end{array}$ & Peas & $\begin{array}{l}\text { Rice or } \\
\text { oatmeal }\end{array}$ & Beef or pork & Rice or oatmeal or peas & Meat & Flour & Rice & Rum & Meat & Flour & Rice & Rum \\
\hline Men & 7 lbs. or 4 lbs. & 7 lbs. or 7 lbs. & 6 oz. or 8 oz. & 3 pts. & $1 / 2 \mathrm{lb}$. or $1 / 2 \mathrm{lb}$. & 7 lbs. or 7 lbs. & 7 pts. or 7 pts. or 3.5 pts & $2 \mathrm{lbs}$. & - & 6 qts. (12 pts.) & 1 pt. & $1 \mathrm{lb}$. & $1 \mathrm{lb}$. & 6 qts. (12 pts) & 3 gils \\
\hline Women & - & - & - & - & - & 7 lbs. or 7 lbs. & 7 pts. or 7 pts. or 3.5 pts & 2 lbs. & 3 lbs. & 4 qts. (8 pts.) & - & $1 \mathrm{lb}$. & $4 \mathrm{lb}$. & 4 qts. (8 pts.) & - \\
\hline Children & - & - & - & - & - & $\begin{array}{l}3.5 \text { lbs. or } 3.5 \\
\text { lbs. }\end{array}$ & 7 pts. or 7 pts. or 3.5 pts & - & 3 lbs. & 3 qts. (6 pts) & - & - & $3 \mathrm{lbs}$. & 3 qts. (6 pts.) & - \\
\hline
\end{tabular}

${ }^{\mathrm{a}}$ For British military rations, see John Robinson to Arnold Nesbitt, Adam Drummond, Moses Franks, John Henniker, William Devaynes, and George Wombell, Whitehall, 17 April 1778, vol. 2, no. 122, photostat 1103, box 5, British Headquarters Papers, NYPL. For rations for the Maroons, see John Gray and T[homas] Ludlum, Estimate of the expense likely to be incurred by the Maroons for Provisions for the first 12 months after their arrival in Africa, supposing them to be in number 560 and about an equal proportion of Men, Women \& Children, Freetown, Sierra Leone, 10 June 1799 , f. 195, CO 267/10, TNA; In Council, 29 April 1801, f. 156, and 21 Aug. 1801, f. 245, CO 270/6, TNA. 
because lazy colonists knew they could expect provisions. ${ }^{80}$ Clarkson changed the company's provisioning structure by requiring people to work for food. In May 1792, he set wages at two shillings per day. Everyone had to work two days out of the week, and colonists bought full rations for six pence or half rations for three pence. ${ }^{81}$ Because it was difficult to obtain money from anyone except company officials, Clarkson's decision meant that those who refused to work could not buy rations, and even those who did work were still expected to pay for food.

The Nova Scotians seized the first opportunity to change Clarkson's system of demanding labour for rations; their actions reflect increasing tendencies to negotiate over the right to food. When in November 1792 Clarkson halved rations, black Loyalist John Strong proposed that if Clarkson did not possess enough stored provisions, he and others would 'work one day for the half raisions', rather than the two days originally mandated. Clarkson could pay the remaining wages in company credit. Other black Loyalists argued that a decrease in provisions should reduce their workload, and warned that a failure to do so would create conflict. Clarkson, who worried that extra pay would encourage drunkenness, compromised by crediting each Loyalist's account. ${ }^{82}$

Black Loyalists complained because they had experienced political economies besides Freetown's. Slaves in North America possessed garden plots for growing vegetables, but enjoyed little time to do so. ${ }^{83}$ Lowcountry slaves' fishing activities cornered the market, though their Chesapeake counterparts did not gain such a monopoly. Southern slave hucksters' prices for dairy, meat, and perishable goods rose higher than those set by whites because slaves had more customers. ${ }^{84}$ Selfliberated slaves took these survival strategies with them to Nova Scotia, where the initial absence of public marketplaces allowed hucksters to buy and sell enough food to profit. $^{85}$ In Africa, the Nova Scotians' land overlapped with Temne territory, meaning that some colonists did not obtain land, and raising garden produce remained impossible. ${ }^{86}$ The rainy season curtailed planting time. ${ }^{87}$ Colonists built fishing boats, but they also risked re-enslavement when venturing along the coast or rivers. ${ }^{88}$ The act of fixing prices became one of their most effective hunger-avoiding strategies.

Colonisation from 1792 to 1793 established significant precedents. People learned that their abilities to fight hunger fluctuated with the rainy season, the availability of ships, trade with Muslim merchants and the Temne, Susu, and Bullom who provided provisions, and black Loyalists' abilities to produce, store, and fix prices. Although colonists sometimes critiqued Clarkson's policies, room remained for compromise. Clarkson sailed for London in December 1792, planning to return, but the Sierra Leone Company fired him while he was in London. ${ }^{89}$ From afar, Clarkson received word that by January land surveying had ceased, and 'there [was] neither beef, Pork, flower or any kind of provision sufficient to last the colony a week'. ${ }^{90}$ Clarkson's governorship had set the stage 
for colonists to demand continued access to food; in doing so under new governor William Dawes's rule, black Loyalists' political rights expanded.

When food shortages continued in 1793, the black Loyalists wrote letters and petitions, pushed for greater representation, and elected representatives who created food legislation. ${ }^{91}$ Although their laws do not negate all conflict with the Sierra Leone Council, they reveal significant cooperation over hunger prevention - which makes the council's decision to call the 1800 event a rebellion into a more significant obfuscation. Given the fact that humans must eat to survive, laws about food would have pervaded political participation in the colony on a daily, visceral level. These food laws, which created conflict with the Temne, likely helped precipitate protest against the Sierra Leone Council.

In October 1793, the colonists sent Isaac Anderson and Cato Perkins to London to petition the Sierra Leone Company. ${ }^{92}$ Anderson and Perkins had lived free in Nova Scotia after escaping slavery in South Carolina by running to the British during the American Revolution. ${ }^{93}$ The men wrote to John Clarkson, and then to the Court of Directors of the Sierra Leone Company. Although they hoped for 'Land ... to make a Crop' before the advent of 'the rainy Season', the company had not allotted land, and 'Health and Life' remained 'very uncertain'. The company store charged 'extortionate' prices, they complained. Perkins and Anderson stated that Governor Dawes dishonestly 'put thirty Gals. of water into a Peck of rum ... \& then [sold] it to us for a Shilling a Galln. more than we ever paid before.${ }^{94}$ Anna Maria Falconbridge confirmed that Dawes was exerting his control over 'almost every kind of provisions in the neighbourhood'. ${ }^{95}$

Perkins and Anderson's petition cited continuing land problems, as scholars have argued. Awareness of the rainy season and the reference to death also suggest the fear of hunger - which was exacerbated by the company's ability to control prices for provisions and alcohol. The black Loyalists argued that they faced an unwelcome choice: they could go into debt by paying exorbitant prices, or they could go hungry. 'We must either get into debt or be starved', Clarkson recorded them saying. ${ }^{96}$ In 1794, the colonists wrote that in his absence they had dubbed Freetown 'A town of Slavery'. ${ }^{97}$ Their formal protest demanded new ways to prevent hunger.

Had the black Loyalists remained in the United States, they would have been disallowed from holding office or serving on juries. ${ }^{98}$ In Freetown, they participated in a system that paved the way for expanded political and legal rights. Governor Dawes and future governor Zachary Macaulay began encouraging colonists to elect representatives. These men, called Hundredors and Tythingmen, appear in council minutes in December $1792 .{ }^{99}$ Every 10 householders formed a tithing, every 10 tithings formed a hundred, 10 freeholders elected a Tythingman, and every 10 Tythingmen elected a Hundredor. Collectively, the Hundredors and Tythingmen proposed regulations that the Sierra Leone Council usually approved. ${ }^{100}$ Colonists requested the right to sit on juries in 1792. ${ }^{101}$ By 1793, when three white sailors came on shore and 'killed a duck 
belonging to one of the Settlers', the thieves were tried, 'by Judge McAuley and a Jury of twelve blacks'. The jury sentenced one man to a lashing, and imposed fines on the other two. Although the master of the sailors' ship dubbed the court 'a mockery on all law and justice', one of the sailors was nevertheless 'whipped by a black man'. ${ }^{102}$ The incident's focus on poultry was significant.

When the black Loyalists realised that scarcity would continue, their Hundredors and Tythingmen created food laws that regulated the prices of black Loyalist-produced commodities and tried to control Africans' abilities to sell meat in the colony. James Sidbury has suggested that the Nova Scotians wanted to use the market without becoming dependent on market relations. ${ }^{103}$ This observation rings true, but black Loyalist food laws also sought to control the market. Previous work has traced how people who lacked power reacted to state-created food systems, and argued that only in the nineteenth century did hunger become preventable. ${ }^{104}$ Black Loyalists' law-making provides evidence of eighteenth-century actors avoiding hunger, not by battling the state, but by working with the government.

Having witnessed Clarkson and then Dawes fixing prices during their governorships, the black Loyalists asked their Hundredors and Tythingmen to set colony-wide prices for bread and meat, and to control alcohol distribution. The Sierra Leone Council probably approved these changes because the precedent for such laws existed within an Anglo-American legal tradition that has come to be known as the moral economy - a term coined by E. P. Thompson. In Thompson's model, during times of scarcity, common folk stopped accepting inequalities of power and wealth to pressure wealthy men into fulfilling their end of the social contract by guaranteeing access to food at a just price. ${ }^{105}$ In 1793, the Hundredors and Tythingmen, with the Sierra Leone Council's approval, proposed laws that standardised prices for beef, goat, pork, and sheep mutton. ${ }^{106}$ Zachary Macaulay had conducted experiments with colonist Pompey Young to price bread at three pence in 1794, but a 1795 resolution of the Hundredors and Tythingmen raised the price to four pence half penny per pound. ${ }^{107}$ When the Hundredors and Tythingmen proposed fining anyone in the colony convicted of selling liquor or wine without a licence, the governor and council went so far as to deem this resolution 'highly proper \& expedient' before passing it. ${ }^{108}$

By 1795, black Loyalists' food laws also aimed to control the prices of edible goods that Africans brought into the colony, thus prompting conflict. Initially, many colonists felt driven by a religious impulse that explained their flight from North America, what they saw as their mission in Africa, and for some, desires to forge bonds with Africans. ${ }^{109}$ Black Loyalists welcomed Africans into Freetown because doing so increased possibilities for Christian conversion as well as trade. In 1796, a group of Methodists even moved to Pirate's Bay with the permission of two Temne headmen, claiming identities as Christian Africans. Most of the colonists, however, would have had trouble identifying as 
Africans. Less than one fourth of them were African-born. Of the 123 heads of households in Birchtown, Nova Scotia who registered interest in migrating to Sierra Leone, 39 per cent were born in the Chesapeake, 31 per cent in Africa, and 24 per cent in the Carolinas. Because these percentages included only adult men, who comprised a larger portion of African slaves, they inflated the African-born figures. ${ }^{110}$ Religious differences between Loyalists and Africans caused significant problems, and language barriers further impeded conversion. ${ }^{111}$ Food laws created additional confrontations.

In 1795, the Hundredors and Tythingmen recommended that the governor and council should 'issue an order to prevent strangers selling Meat in the Colony by Retail'. Susu men had brought 'some fine Cattle' into Freetown, but refused to sell them unless the Nova Scotians allowed them 'to kill them and sell them out by the Pound'. The Nova Scotians did 'not think that is proper', and requested 'that no strangers or People that doth not belong to the Colony should bring live stock here and kill them'. ${ }^{112}$ In this context, 'by Retail' meant sales of pre-butchered meat - likely meat butchered according to Muslim dietary laws. Colonists wanted Susu to sell only live animals because it became difficult to regulate prices for butchered meat.

The Nova Scotians' use of the word 'strangers' evoked the landlord-stranger relationship. Within Sierra Leone, Temne elite offered protection as landlords of British and Nova Scotian strangers. At the same time that Freetown's residents were strangers, early Muslim immigrants in Freetown were also strangers. ${ }^{113}$ As Bruce Mouser has suggested, the landlord-stranger relationship allowed foreigners to influence African social structures in ways that fostered accommodation and assimilation rather than control. ${ }^{114}$ By calling Susu traders strangers, the Nova Scotians claimed landlord status over them, but in passing a regulation that ignored strangers' food practices, they decreased the possibility for compromise. It is clear that the council voiced no objections.

It is difficult to say what Loyalists intended by these laws. Maybe they meant to try to exercise power, and maybe they only wanted to avoid hunger. Historians must turn to African reactions to understand the laws' effects. In the late 1790s, Temne words and actions indicate dissatisfaction. In 1798, King Tom appeared at a palaver (or meeting) and claimed that Zachary Macaulay 'had spoiled the Country ... by lowering the Price of Produce'. He cited the decreased cost of rice, and argued, 'that if Mr. Macaulay wished to do good to the Country, he must again give the same'. Macaulay refused, and was told that he had to agree, or leave the country. Macaulay 'could not do the one, nor yet would he do the other', and so King Tom 'departed in great Anger'. ${ }^{115}$ It is unclear whether prices really had decreased. The Freetown colony could not have retained much control over prices outside the colony, given their dependency on African trade networks for food. In 1802, Freetown suffered because slave ship captains were demanding high prices for produce. ${ }^{116}$ Macaulay's interaction 
with King Tom thus becomes difficult to explain, but the important point is that King Tom held the colony responsible for shifting prices.

Other incidents indicate additional conflict between colonists and Africans. In 1797, Macaulay reported a great 'Mortality among the Settlers hogs'. No one could detect a cause until an unidentified 'Native was caught in the very act of laying Ratsbane enclosed in Cassada near some Hogs, evidently for the purpose of killing them'. Macaulay speculated that had the man succeeded, 'the Natives wd. have ... begged the dead body of the owner, and thus have had a Supply of fresh meat at very little expence'. ${ }^{117}$ It is possible that the poisoner planned to sell the carcass back to the colonists. Fears about contaminated produce may even have prompted regulations about meat sales.

When Temne-Nova Scotian conflict became obvious in the late 1790s, the Sierra Leone Council became unwilling to sanction the Hundredors' and Tythingmens' laws. An encounter in December 1796 presents one of the first instances of a white official challenging an elected black Loyalist's policies. Zachary Macaulay described his discovery of Hundredor Ishmael York 'Selling rum to the Natives at ... a Sixpence more [per] Gallon from Natives'. York argued that, 'He did not See why any one Shd. interfere in his trade with the natives'. Macaulay, unmoved by York's logic, revoked his liquor licence. ${ }^{118}$ It is possible that York was implying that colonists should enjoy more preferential prices than Africans. In his meeting with Macaulay, York specifically averred his right to fix his own prices. Not coincidentally, he was one of the 1800 protestors.

Not only did the Sierra Leone Council curtail black Loyalists' abilities to set prices; it also stopped enforcing Nova Scotian regulations about animals. 'Many cattle belonging to the Colony were killed by the Natives' in 1799. When some of the culprits had been identified, 'a serious complaint was made to King Tom, who promised redress'. Before he could remedy the matter, however, 'another Cow ... was stolen in the same manner'. In an act of Nova Scotian-imposed justice, the colonists 'armed themselves, went in to King Tom's Territory', and seized several suspects. Governor Thomas Ludlum reported that King Tom gained 'an advantage' by capturing three colonists, and then arguing that the fact that they acted without the council's consent negated his obligation to pay for the animals. Councilmen sought no reparation, and indeed Ludlum's report of the incident indicated a growing divide between the council's ideas about government and those of the Nova Scotians. ${ }^{119}$ It seems likely that colonists used extra-legal violence to solve the matter because they doubted the council's willingness to administer their laws. This was not just an episode of one white councilman forbidding a Nova Scotian to charge what he wanted; it was a record of disintegrating cooperation between black Loyalists and the council. The most persuasive explanation for this reversal in policy is that councilmen deemed it expedient to acquiesce to elite landlords' power in order to avoid more serious violence. 
In 1798, the black Loyalists again asserted their political rights. They appointed Methodist preacher Mingo Jordan as judge, and Isaac Anderson and John Cuthbert became justices of the peace. Douglas Egerton has suggested that these appointments marked the last step before rebellion. ${ }^{120}$ Yet these actions merely built on the government established through the Hundredors and Tythingmen after 1792. Jordan, Anderson, and Cuthbert assumed elected positions because of a precedent in the appointment of an all-black jury, and in the formulation of Hundredor- and Tythingmen-conceived (and councilapproved) laws. It was their positions as officeholders, and their history of law-making that should have legitimised the Hundredors' and Tythingmens' 1800 attempt to fix food prices with the code of laws.

Although one could argue that the 1800 Freetown incident was a rebellion, considering its similarities to food riots contextualises the laws that black Loyalists enacted to avoid hunger, and uncovers more friction between the Loyalists, the Susu, and the Temne, and more cooperation between the Loyalists and the Sierra Leone Council. It also makes the council's description of the 1800 'rebellion' into a more significant contradiction. By initially establishing prices for alcohol, bread, and fish, and regulating the sale of meat, free black Loyalists privileged their ability to fight hunger over their relationships with Africans - and at first they did so with the blessings of the council. Clarkson and then the Sierra Leone Council opened the door to changes in government by approving pricefixing, jury service, and legislation. Only in the late 1790s did whites question these decisions.

As Isaac Land and Andrew Shocket suggest, Sierra Leone straddles oppositional categories: the first or second British empire, formal or informal imperialism, settler or non-settler societies, colonisers or colonised, and old or new. ${ }^{121}$ Like colonists of the first British Empire, Nova Scotians tried to acquire land, but they also focused on trade. They acted like powerful colonists, but also lost power to the Sierra Leone Council, who feared even more powerful Africans. That black Loyalists in Sierra Leone failed to forge common bonds with the Temne should not come as a surprise because of the contradictions of the Freetown experiment.

Black Loyalists, like their contemporaries in Britain and the American colonies, sought more control of their local economy. In Britain, the Corn Laws protected the price of grain and were not repealed until $1846 .{ }^{122}$ During and after the American Revolution, Americans increasingly acknowledged the viability of protectionism - a mentality that persisted throughout most of the nineteenth century. ${ }^{123}$ Nova Scotians favoured similar laws that fixed prices for the food that they daily produced, bought, and sold. They wanted fair prices, but they also demonstrated a desire to be the people legislating price-fixing. The Sierra Leone Council overruled them; in December 1800, it eliminated import and export duties on all foodstuffs, pushing the colony closer towards freer trade. $^{124}$ Temne attacks in 1801 and 1802 threatened the colony, as did the 
failure of African food crops in 1803. In August 1808, the British Crown assumed formal rule of Freetown. ${ }^{125}$

Black Loyalists in Sierra Leone created political rights in part through the passage of food laws. In so doing, they precipitated violent encounters with the Temne, conflicts with white officials, and, possibly, riot. White officials did not find fault with Nova Scotian price-fixing - with a few significant exceptions in the late 1790s, and in their refusal to legitimise black Loyalist price-fixing in 1800. Calling the 1800 event a riot recognises that the Loyalists were acting not as rebellious slaves but as an organised group of emancipated political participants. Although the black Loyalists gained only transient freedoms through their food laws, their narrative presents a model that should encourage scholars to look forward and backward in time to consider how hunger in the Atlantic littoral brought people together and drove them apart.

\section{Acknowledgements}

The author thanks Edward Andrews, Amanda Behm, Carolyn Eastman, Neil Kamil, Matt Kelly, Marc-William Palen, Cassandra Pybus, James Sidbury, and Adam Tooze for reading and commenting at various stages on this essay.

\section{Disclosure statement}

No potential conflict of interest was reported by the author.

\section{Funding}

Work was supported by the New York Public Library under a short-term fellowship; the Huntington Library under a short-term fellowship; the McNeil Center for Early American Studies under a Society of Cincinnati and Friends of MCEAS fellowship; and International Security Studies at Yale under a Smith Richardson Predoctoral fellowship.

\section{Notes}

1. Paper of Laws stuck up at Abram Smith's house by the Hundredors and Tythingmen, Appendix, ff. 98-100, CO 270/5, the National Archives, Kew, UK (hereafter TNA); A Narrative of the Rebellion which broke out in this Colony on the $25^{\text {th }}$ of Septr. 1800 , Appendix, ff. 100-11, CO 270/5, TNA.

2. Maya Jasanoff, Liberty's Exiles: American Loyalists in the Revolutionary World (New York: Alfred A. Knopf, 2011), 304-5; Ellen Gibson Wilson, The Loyal Blacks (New York: Capricorn Books, 1976), 388-96.

3. Here I follow Barry Cahill in referring to colonists as Loyalists and Nova Scotians only once they left the Maritimes. Barry Cahill, 'The Black Loyalist Myth in Atlantic Canada', Acadiensis XXIX, no. 1 (Autumn 1999), http://journals.hil.unb.ca/index. php/acadiensis/article/view/10801/11587, esp. paras. 3, 8.

4. Christopher Fyfe, A History of Sierra Leone (London: Oxford University Press, 1962); Robin W. Winks, The Blacks in Canada: A History (New Haven, CT: Yale University 
Press, 1971); James W. St. G. Walker, The Black Loyalists: The Search for a Promised Land in Nova Scotia and Sierra Leone 1783-1870 (New York: Africana Publishing Company, 1976); Wilson, The Loyal Blacks; Ellen Gibson Wilson, John Clarkson and the African Adventure (London and Basingstoke: Macmillan Press, 1980); Neil MacKinnon, This Unfriendly Soil: The Loyalist Experience in Nova Scotia 1783-1791 (Kingston and Montreal: McGill-Queen's University Press, 1986); Mary Louise Clifford, From Slavery to Freetown: Black Loyalists after the American Revolution (Jefferson: McFarland, 1999).

5. Deirdre Coleman, Romantic Colonization and British Anti-slavery (Cambridge: Cambridge University Press, 2005); W. Bryan Rommel-Ruiz, 'Colonizing the Black Atlantic: The African Colonization Movements in Postwar Rhode Island and Nova Scotia', Slavery \& Abolition 27, no. 3 (Dec. 2006): 349-65; Emma Christopher, 'A “Disgrace to the Very Colour": Perceptions of Blackness and Whiteness in the Founding of Sierra Leone and Botany Bay', Journal of Colonialism and Colonial History 9, no. 3 (Winter 2008), http://muse.jhu.edu/journals/journal_of_colonialism_and_colonial_ history/v009/9.3.christopher.html; Bronwen Everill, Abolition and Empire in Sierra Leone and Liberia (Basingstoke, UK: Palgrave Macmillan, 2013).

6. Moving On: Black Loyalists in the Afro-Atlantic World, ed. John W. Pulis (New York: Garland, 1999); Cahill, 'The Black Loyalist Myth in Atlantic Canada'; Jasanoff, Liberty's Exiles; Cassandra Pybus, Epic Journeys of Freedom: Runaway Slaves of the American Revolution and Their Global Quest for Liberty (Boston: Beacon Press, 2006); James Sidbury, Becoming African in America: Race and Nation in the Early Black Atlantic (New York: Oxford University Press, 2007); Alexander X. Byrd, Captives and Voyagers: Black Migrants Across the Eighteenth-Century British Atlantic World (Baton Rouge: Louisiana State University Press, 2008); Isaac Land and Andrew M. Schocket, eds., 'Special Issue: New Approaches to the Founding of the Sierra Leone Colony, 17861808', Journal of Colonialism and Colonial History 9, no. 3 (Winter 2008), http:// muse.jhu.edu/journals/journal_of_colonialism_and_colonial_history/toc/cch.9.3.html; Paul E. Lovejoy and Suzanne Schwarz, eds., Slavery, Abolition and the Transition to Colonialism in Sierra Leone (Trenton: Africa World Press, 2015); Janet Polasky, Revolutions Without Borders: The Call to Liberty in the Atlantic World (New Haven, CT: Yale University Press, 2015).

7. For 1795, see Fyfe, A History of Sierra Leone, 64. For the laws as domestic, see Wilson, The Loyal Blacks, 391.

8. Cassandra Pybus, 'Henry 'Harry' Washington (1750s-1790s): A Founding Father's Slave', in The Human Tradition in the Atlantic World, 1500-1850, ed. Karen Racine and Beatriz G. Mamigonian (Lanham, MD: Rowman \& Littlefield, 2010), 101-15, esp. 113.

9. James Sidbury, “African” Settlers in the Founding of Freetown', in Slavery, Abolition and the Transition to Colonialism in Sierra Leone, ed. Paul E. Lovejoy and Suzanne Schwarz (Trenton: Africa World Press, 2015), 127-41.

10. For cash crops, see Coleman, Romantic Colonization, 132; Suzanne Schwarz, 'From Company Administration to Crown Control: Experimentation and Adaptation in Sierra Leone in the Late Eighteenth and Early Nineteenth Centuries', in Slavery, Abolition and the Transition to Colonialism in Sierra Leone, ed. Paul E. Lovejoy and Suzanne Schwarz (Trenton: Africa World Press, 2015), 173-4; Everill, Abolition and Empire in Sierra Leone and Liberia, 19. For white colonists' interactions with the Temne, see Rachel B. Herrmann, "If the King Had Really Been a Father to Us": Failed Food Diplomacy in Eighteenth-Century Sierra Leone', in The Routledge History of Food, ed. Carol Helstosky (New York: Routledge, 2014), 92-112. For food in Freetown between 1792 
and 1803, see Philip R. Misevich, 'On the Frontier of "Freedom:” Abolition and the Transformation of Atlantic Commerce in Southern Sierra Leone, 1790s to 1860s' (Ph.D. thesis, Emory University, 2009); Misevich, 'The Sierra Leone Hinterland and the Provisioning of Early Freetown, 1792-1803', Journal of Colonialism and Colonial History 9, no. 3 (Winter 2008).

11. Recapitulation of the number of Negroes who have availed themselves of the Late Commanders in Chiefs Proclamations by comming in within the British Lines in North America ..., photostat 1047, f. 257, box 43, British Headquarters Papers, the New York Public Library, New York, NY (hereafter NYPL); Maya Jasanoff, 'The Other Side of the Revolution: Loyalists in the British Empire', William and Mary Quarterly 65, no. 2 (April 2008): 205-32, esp. 208.

12. Fyfe, A History of Sierra Leone, 34-47; Winks, The Blacks in Canada, Ch. 2.

13. For Senegambia, see Paul E. Lovejoy, 'Forgotten Colony in Africa: The British Province of Senegambia (1765-83)', in Slavery, Abolition and the Transition to Colonialism in Sierra Leone, ed. Paul E. Lovejoy and Suzanne Schwarz (Trenton: Africa World Press, 2015), 109-25. For Bulama, see Coleman, Romantic Colonization, 88. For Granville Town, see Sidbury, Becoming African in America, 53. For the Black Poor, see George E. Brooks, Eurafricans in Western Africa: Commerce, Social Status, Gender, and Religious Observance from the Sixteenth to the Eighteen Century (Athens: Ohio University Press, 2003), 306.

14. For the Sierra Leone Company, see Wilson, John Clarkson and the African, 55-6. For Thomas Peters, see Petition of Thomas Peters, 1791, enclosed in John Clarkson to William Wilberforce, [c. after Aug. 18, 1815], ff. 155-6, Add. MS 41263, BL; [Memorial of Thomas Peters,] enclosed in [Unknown] to Governor Parr, Whitehall, 6 Aug. 1791, f. 80, CO 217/72, TNA; Winks, The Blacks in Canada, 61-3.

15. Sidbury, Becoming African in America, 98.

16. For the latter, see E. P. Thompson, 'The Moral Economy of the English Crowd in the Eighteenth Century', Past \& Present, no. 50 (Feb. 1971): 76-136; Cynthia A. Bouton, The Flour War: Gender, Class, and Community in Late Ancien Régime French Society (University Park: The Pennsylvania State University Press, 1993); John Walton and David Seddon, Free Markets \& Food Riots: The Politics of Global Adjustment (Cambridge: John Wiley, 1994); Barbara Clark Smith, 'Food Rioters and the American Revolution', William and Mary Quarterly, 3d series, 51, no. 1 (Jan. 1994): 3-38; Andy Wood, Riot, Rebellion and Popular Politics in Early Modern England (Basingstoke, UK: Palgrave Macmillan, 2002); John Bohstedt, The Politics of Provisions: Food Riots, Moral Economy, and Market Transition in England, c. 1550-1850 (Surrey: Ashgate, 2010).

17. The code was dated 3 Sept. Paper of Laws stuck up at Abram Smith's house by the Hundredors and Tythingmen, Appendix, f. 98-100, CO 270/5, TNA.

18. A Narrative of the Rebellion which broke out in this Colony on the 25th of Septr. 1800, Appendix, ff. 100 (for the postings of the code), 102 (for the scuffle, the $27^{\text {th }}$, and the bridge), 104 (for pillaging), CO 270/5, TNA; Wilson, The Loyal Blacks, 392 (for the bayonet).

19. Jasanoff, Liberty's Exiles, 304; C. Magbaily Fyle, Historical Dictionary of Sierra Leone (Lanham, MD: The Scarecrow Press, 2006), 210-11.

20. For the Maroons, see [John King] to John Schoolbred, Whitehall, 7 July 1796, f. 139, CO 267/10, TNA. For the soldiers, see f. 105, CO 270/5, TNA. For slightly different numbers, see Douglas R. Egerton, Death or Liberty: African Americans and Revolutionary America (New York: Oxford University Press, 2009), 220.

21. Before departing Nova Scotia, John Clarkson had assured the Loyalists that they would be exempt from quitrent payments - a promise the council did not keep. In 1794 the 
council intended to force payment of a quitrent 10 times higher than any of those in America, despite many colonists remaining landless. For Clarkson's promises, see Fyfe, A History of Sierra Leone, 34. For quitrent rates in Sierra Leone, see Wilson, The Loyal Blacks, 189. For primary documents, see Resolution of Council Omitted, [?] Jan. 1794, f. 139, CO 270/2, TNA; Henry Thornton to John Clarkson, London, 30 Dec. 1791, f. 41, Add MS. 41262A, BL; Zachary Macaulay and James Watt to the Chairman and Court of Directors of the Sierra Leone Company, Freetown, 15 Nov. 1794, f. 2, Journal of Zachary Macaulay, MY 418 (7), Macaulay Papers, the Huntington Library, San Marino, CA, (hereafter HL).

22. Fyfe, A History of Sierra Leone, 68, 81-7; Wilson, The Loyal Blacks, 383-401; Clifford, From Slavery to Freetown, 189-96; Pybus, Epic Journeys of Freedom, 191-202; Egerton, Death or Liberty, 219; Jasanoff, Liberty's Exiles, 304-7; Sidbury, Becoming African in America, 125-8.

23. A Narrative of the Rebellion which broke out in this Colony on the 25th of Septr. 1800, Appendix, f. 100, CO 270/5, TNA.

24. A Narrative of the Rebellion which broke out in this Colony on the 25th of Septr. 1800, Appendix, ff. 100-11, CO 270/5, TNA; Report from the Committee on the Petition of the Court of Directors of the Sierra Leone Company, 1802. House of Commons Parliamentary Papers Online, http://gateway.proquest.com/openurl?url_ver=Z39.88-2004\&res_ dat=xri:hcpp\&rft_dat=xri:hcpp:rec:1801-000196.

25. For representative examples, see Peter Wood, Black Majority: Negroes in Colonial South Carolina: From 1670 Through the Stono Rebellion (New York: Alfred A. Knopf, 1974); Gad Heuman, 'The Killing Time': The Morant Bay Rebellion in Jamaica (London: University of Tennessee Press, 1994); James Sidbury, Ploughshares into Swords: Race, Rebellion, and Identity in Gabriel's Virginia, 1730-1810 (New York: Cambridge University Press, 1997).

26. Paul A. Gilje, Rioting in America (Bloomington: Indiana University Press, 1996), 6.

27. Michael Naragon, 'From Chattel to Citizen: The Transition from Slavery to Freedom in Richmond, Virginia', Slavery \& Abolition 21, no. 2 (2000): 93-116, esp. 112.

28. Julie Saville, 'Rites and Power: Reflections on Slavery, Freedom and Political Ritual', Slavery and Abolition 20, no. 1 (1999): 84-5; Natasha Lightfoot, "Their Coats Were Tied Up like Men”: Women Rebels in Antigua’s 1858 Uprising', Slavery \& Abolition 31, no. 4 (Nov. 2010): 527-45; Stephan Lenik, 'Plantation Labourer Rebellions, Material Culture and Events: Historical Archaeology at Geneva Estate, Grand Bay, Commonwealth of Dominica', Slavery \& Abolition 35, no. 3 (Sept. 2014): esp. 518-19.

29. On rebellious behaviour, see Edward A. Pearson, “A Countryside Full of Flames': A Reconsideration of the Stono Rebellion and Slave Rebelliousness in the Early Eighteenth-Century South Carolina Lowcountry', Slavery \& Abolition 17, no. 2 (1996): 22-50, esp. 38-9.

30. Pybus, 'Henry "Harry" Washington (1750s-1790s)', 113

31. On colonists taking office, see In Council, 5 Jan. 1799, f. 234, CO 270/4, TNA. On land and subjecthood, see Coleman, Romantic Colonization, 109.

32. For King Tom's actions in 1800, see Jasanoff, Liberty's Exiles, 304, Egerton, Death or Liberty, 219-20; Sidbury, “African” Settlers in the Founding of Freetown', 138; Wilson, The Loyal Blacks, 396. Background on King Tom is contradictory. C. Magbaily Fyle states that King Tom was the subruler around the Rokel River estuary and observes that his son, Henry, studied in England. George Brooks and Christopher Fyfe say that this King Tom, known as Panabouré Forbana, died in 1788, and Cassandra Pybus suggests that it was King Naimbana's son Henry who studied in England. Fyle identifies King Tom as Pa Kokelly, and says that by 
decision of the Bai Farma Kokelly replaced King Jimmy in the mid-1790s. Whether there was one King Tom or two, the Pa Kokelly of the late 1790s was angered by continuing land disputes with the Colony. Fyle, Historical Dictionary of Sierra Leone, 21011; Brooks, Eurafricans in Western Africa, 299; Fyfe, A History of Sierra Leone, 22; Cassandra Pybus, “A Less Favourable Specimen”: The Abolitionist Response to Self-emancipated Slaves in Sierra Leone, 1793-1808', Parliamentary History 26, Issue Supplement S1 (June 2007): 99n12.

33. A Narrative of the Rebellion which broke out in this Colony on the 25th of Septr. 1800, Appendix, f. 102, CO 270/5, TNA.

34. Report from the Committee on the Petition of the Court of Directors of the Sierra Leone Company, 1802, 13.

35. On King Tom, see Fyle, Historical Dictionary of Sierra Leone, 211. On Bai Farma, see Fyle, The History of Sierra Leone: A Concise Introduction (London: Evans, 1981), 16-17.

36. Bruce L. Mouser, 'Rebellion, Marronage and Jihäd: Strategies of Resistance to Slavery on the Sierra Leone Coast, c. 1783-1796', Journal of African History 48, no. 1 (2007): 27-44, esp. 33; Ismail Rashid, 'Escape, Revolt, and Marronage in Eighteenth and Nineteenth Century Sierra Leone Hinterland', Canadian Journal of African Studies/Revue Canadienne des Études Africaines 34, no. 3 (2000): 656-83, esp. 667.

37. Rashid, 'Escape, Revolt, and Marronage in Eighteenth and Nineteenth Century Sierra Leone Hinterland', 668.

38. Report from the Committee on the Petition of the Court of Directors of the Sierra Leone Company, 1802, 4.

39. For England, see Bohstedt, The Politics of Provisions, 2. For America, see Barbara Clark Smith, 'Food Rioters and the American Revolution', William and Mary Quarterly 3d series, 51, no. 1 (Jan. 1994): 3; Wayne E. Lee, Crowds and Soldiers in Revolutionary North Carolina: The Culture of Violence in Riot and War (Gainesville: University Press of Florida, 2001).

40. Bohstedt, The Politics of Provisions, 192, 217.

41. Walton and Seddon, Free Markets \& Food Riots, 25-6.

42. Thompson, 'The Moral Economy of the English Crowd in the Eighteenth Century', 115; John Bohstedt, 'Gender, Household and Community Politics: Women in English Riots 1790-1810’, Past \& Present 120, no. 1 (Aug. 1988): 88-122; Lightfoot, “"Their Coats Were Tied Up like Men”, 537.

43. Isaac Anderson, [N.D.], in 'Our Children Free and Happy': Letters from Black Settlers in Africa in the 1790s, ed. Christopher Fyfe (Edinburgh: Edinburgh University Press, 1991), 65.

44. Tilly, 'Food Supply and Public Order in Modern Europe', 443.

45. For England and France, see Bohstedt, The Politics of Provisions, 224; Tilly, 'Food Supply and Public Order in Modern Europe', 383. For America, see Gilje, Rioting in America, 25.

46. Fyfe, A History of Sierra Leone, 20.

47. Rashid, 'Escape, Revolt, and Marronage in Eighteenth and Nineteenth Century Sierra Leone Hinterland', 662.

48. Bruce L. Mouser, 'Landlords-Strangers: A Process of Accommodation and Assimilation', The International Journal of African Historical Studies 8, no. 3 (1975): 425-40, esp. 428; Brooks, Eurafricans in Western Africa, xxiii, 200-1, 293; Fyle, The History of Sierra Leone, 27.

49. Rashid, 'Escape, Revolt, and Marronage in Eighteenth and Nineteenth Century Sierra Leone Hinterland', 663.

50. Brooks, Eurafricans in Western Africa, 249, 295; Fyle, The History of Sierra Leone, 31. 
51. Fyle, The History of Sierra Leone, 16-17, 31, 54.

52. Fyfe, A History of Sierra Leone, 1-10, 19, 54; Kenneth C. Wylie, The Political Kingdoms of the Temne: Temne Government in Sierra Leone, 1825-1910 (New York: Africana, 1977), xiii, xv, 3; Fyfe, A History of Sierra Leone, 47.

53. Rev. E. G. Ingham, Sierra Leone after a Hundred Years (London: Frank Cass, 1968 [1894]), 80; 5 March 1798, f. 193, CO 270/4, TNA.

54. Anna Maria Falconbridge, Narrative of Two Voyages to the River Sierra Leone During the Years 1791-1792-1793, ed. Christopher Fyfe (Liverpool: Liverpool University Press), 1, 4, 95 .

55. Wilson, John Clarkson and the African Adventure, 86.

56. Winks, The Blacks in Canada, 74-5.

57. Falconbridge, Narrative of Two Voyages, 76.

58. 12 Jan. 1793, f. 5, Add. MS 41263, BL.

59. Ingham, Sierra Leone after a Hundred Years, 74 ('dying'), 76, 91-2 ('damaged', 'a stench', and 'allowed').

60. Misevich, 'On the Frontier of "Freedom"', 115n36.

61. Misevich, 'The Sierra Leone Hinterland and the Provisioning of Early Freetown, 17921803'; Misevich, 'On the Frontier of "Freedom"', 109, 115.

62. Zachary Macaulay and James Watt to the Chairman and Court of Directors of the Sierra Leone Company, Freetown, 15 Nov. 1794, f. 1, Journal of Zachary Macaulay, MY 418 (7), Macaulay Papers, HL; Ad[am] Afzelius to the Governor \& Council of Sierra Leone, 27 Nov. 1794, f. 186-7, Add. MS 12131, BL. For the wounded, see 'An Account of the Life of Mr. DAVID GEORGE, from Sierra Leone in Africa; given by himself in a Conversation with Brother RIPPON of London, and Brother PEARCE of Birmingham' (London, 1793-1797), in Unchained Voices: An Anthology of Black Authors in the English-Speaking World of the Eighteenth Century, ed. Vincent Carretta (Lexington: The University Press of Kentucky, 1996), 344.

63. 18 Oct. 1794, Journal of Zachary Macaulay, MY 418 (4), HL.

64. Philip Misevich, 'Freetown and "Freedom?": Colonialism and Slavery in Sierra Leone, 1790s to 1861', in Slavery, Abolition and the Transition to Colonialism in Sierra Leone, ed. Paul E. Lovejoy and Suzanne Schwarz (Trenton: Africa World Press, 2015), 189216, esp. 190.

65. Mouser, 'Rebellion, Marronage and Jihäd', 32.

66. Mouser, 'Landlords-Strangers', 425.

67. Allen M. Howard, 'The Relevance of Spatial Analysis for African Economic History: The Sierra Leone-Guinea System', Journal of African History 17, no. 3 (1976): 36588, esp. 373.

68. Howard, 'The Relevance of Spatial Analysis for African Economic History', 374; Fyle, The History of Sierra Leone, 9, 23.

69. Mouser, 'Landlords-Strangers', 431.

70. Misevich, 'On the Frontier of "Freedom"', 31 (for rice), 36-7 (for kola nuts and salt); Allen M. Howard, 'Nineteenth-Century Coastal Slave Trading and the British Abolition Campaign in Sierra Leone', Slavery \& Abolition 27, no. 1 (Apr. 2006): 28 (for rice).

71. Schwarz, 'From Company Administration to Crown Control', 173-4.

72. 17 March 1792, f. 13, Add. MS 41264, BL; 23 Oct. 1792, 'Diary of Lieutenant J. Clarkson', 91.

73. Zachary Macaulay to Henry Thornton, Thornton Hill, 7 June 1797, Journal of Zachary Macaulay, MY 418 (21), Macaulay Papers, HL.

74. Thomas Clarkson to John Clarkson, 2 Jan. 1792, f. 68, Add. MS 41262A, BL. 
75. Report from the Committee on the Petition of the Court of Directors of the Sierra Leone Company, 1802, 8.

76. 8 Aug. 1793, Journal of Zachary Macaulay, f. 118, MY 418 (1), Macaulay Papers, HL.

77. For this second estimate, see Misevich, 'On the Frontier of "Freedom", 145. For the population count, see Clifford, From Slavery to Freetown, 136.

78. Ingham, Sierra Leone after a Hundred Years, 122; 21 Sept. and 2 Nov. 1792, 'Diary of Lieutenant J. Clarkson', 51, 94; 15 Sept. 1792, 'Diary of Lieutenant J. Clarkson’, 49.

79. 31 Aug. and 1 Sept. 1792, 'Diary of Lieutenant J. Clarkson', 34.

80. Ingham, Sierra Leone after a Hundred Years, 65.

81. 19 Nov. 1792, 'Diary of Lieutenant J. Clarkson', 106; Council Minutes, 12 May 1792, ff. 37-8, CO 270/2, TNA.

82. John Strong to John Clarkson, Freetown, 19 Nov. 1792; [Captains of companies] to John Clarkson, Freetown, 18 Nov. 1792; 19 Nov. 1792, all in 'Diary of Lieutenant J. Clarkson', 105-6. See also Luke Jordan to John Clarkson, 18 Nov. 1792, in Fyfe, 'Our Children Free and Happy', 28.

83. For comparative examples, see Sidney W. Mintz and Richard Price, An Anthropological Approach to the Afro-American Past: A Caribbean Perspective (Philadelphia: A Publication of the Institute for the Study of Human Issues, 1976), 38; Woodville K. Marshall, 'Provision Ground and Plantation Labour in Four Windward Islands: Competition for Resources During Slavery'; Sidney W. Mintz, 'The Origins of the Jamaican Market System'; and Hilary McD. Beckles, 'An Economic Life of Their Own: Slaves as Commodity Producers and Distributors in Barbados', in The Slavery Reader, ed. Gad Heuman and James Walvin (London: Routledge, 2003), 472, 507-20, 521-44, esp. 531-3.

84. Dylan C. Penningroth, The Claims of Kinfolk: African American Property and Community in the Nineteenth-Century South (Chapel Hill: University of North Carolina Press, 2003), esp. 46-9; Philip D. Morgan, Slave Counterpoint: Black Culture in the Eighteenth-Century Chesapeake and Lowcountry (Chapel Hill: University of North Carolina Press, 1998), 240, 242, 252.

85. John Wentworth to the Duke of Portland, Halifax, Nova Scotia, 24 May 1800, f. 203, CO 217/73, TNA.

86. Report from the Committee on the Petition of the Court of Directors of the Sierra Leone Company, 1802, 8.

87. Cato Pirkins and Isaac Anderson to the Hble the Chairmain \& Court of Directors of the Sierra Leone Company London [sent to John Clarkson 30 Oct. 1793], 13 Oct. 1793, ff. 98-9, Add. MS 41263, BL.

88. Report from the Committee on the Petition of the Court of Directors of the Sierra Leone Company, 1802, 10.

89. Wilson, John Clarkson and the African Adventure, 127, 130-5.

90. Journal of Isaac Du Bois, sent to John Clarkson, 14 Jan. 1793 and10 Jan. 1793, ff. 6, 4, Add. MS 41263, BL.

91. Sidbury, “African” Settlers in the Founding of Freetown', 132.

92. Wilson, John Clarkson and the African Adventure, 134.

93. Pybus, Epic Journeys of Freedom, 23, 209, 215.

94. Cato Pirkins and Isaac Anderson to the Hble the Chairmain \& Court of Directors of the Sierra Leone Company London [sent to John Clarkson 30 Oct. 1793] 13 Oct. 1793, ff. 98-9, Add. MS 41263, BL. Clarkson's copy of the petition is underlined. I have edited all underlining into italics.

95. Falconbridge, Narrative of Two Voyages, 105-6.

96. Ingham, Sierra Leone after a Hundred Years, 80. 
97. Moses Wilkinson, Isaac Anderson, [?] Peters, James Hutchinson, Luke Jordan, Jno. Jordan, Burbin Simmons, Amarica Tolbert, and a Great many More the paper wont aford to John Clarkson, Sierra Leone, 19 Nov. 1794, f. 114, Add. MS 41263, BL.

98. Ariela J. Gross, Double Character: Slavery and Mastery in the Antebellum Southern Courtroom (Princeton, NJ: Princeton University Press, 2000), 53-4.

99. 31 Dec. 1792 , f. 66, CO 270/2, TNA.

100. Fyfe, A History of Sierra Leone, 16, 48.

101. Beverhout Company to John Clarkson, 26 June 1792, in Fyfe, 'Our Children Free and Happy', 26.

102. Falconbridge, Narrative of Two Voyages, 124.

103. Sidbury, Becoming African in America, 93-4.

104. For reactions to state food systems, see Jeffrey M. Pilcher, $i$ Que Vivan los Tamales! Food and the Making of Mexican Identity (Albuquerque: University of New Mexico Press, 1998), 2; Nick Cullather, 'The Foreign Policy of the Calorie', American Historical Review 112, no. 2 (Apr. 2007): 337-64. For hunger, see James Vernon, Hunger: A Modern History (Cambridge, MA: Harvard University Press, 2007), 2, 11.

105. Thompson, 'The Moral Economy of the English Crowd in the Eighteenth Century'.

106. 4 July 1793, f. 77, CO 270/2, TNA. See also 21 Aug. 1794, Journal of Zachary Macaulay, MY 418 (3), Macaulay Papers, HL; Resolutions of Council, 23 Aug. 1794, Freetown, Sierra Leone, ff. 5-6, CO 270/3, TNA.

107. Resolutions of Council, Freetown, Sierra Leone, 23 Aug. 1794, f. 5, CO 270/3, TNA; In Council, 9 June 1795, f. 174, CO 270/3, TNA.

108. In Council, 12 Oct. 1795, ff. 230-3, CO 270/3, TNA.

109. For black missionaries, see Edward E. Andrews, Native Apostles: Black and Indian Missionaries in the British Atlantic World (Cambridge, MA: Harvard University Press, 2013).

110. Sidbury, “African” Settlers in the Founding of Freetown', 129, 131, 134-5, 139n5.

111. Falconbridge, Narrative of Two Voyages, 110; Wallace Brown, 'The Black Loyalists in Sierra Leone' in Moving On: Black Loyalists in the Afro-Atlantic World, ed. John W. Pulis (New York: Garland, 1999), 103-34, esp. 120.

112. Richard Corankapoor and Thomas Jackson to [the Governor and Council], Free Town, 8 June 1795, ff. 174-5, CO 270/3, TNA.

113. David E. Skinner, 'The Incorporation of Muslim Elites into the Colonial Administrative Systems of Sierra Leone, the Gambia, and the Gold Coast', Journal of Muslim Minority Affairs 29, no. 1 (2009): 91-108, esp. 94.

114. Mouser, 'Landlords-Strangers', 425.

115. 6 Jan. 1798 , ff. 184-5, CO 270/4, TNA.

116. Misevich, 'On the Frontier of "Freedom", 11.

117. 12 Sept. 1797, Journal of Zachary Macaulay, MY 418 (22), Macaulay Papers, HL.

118. 22 Dec. 1796, Journal of Zachary Macaulay, MY 418 (17), Macaulay Papers, HL.

119. In Council, 24 June 1799, f. 269, 272, CO 270/4, TNA.

120. Egerton, Death or Liberty, 219.

121. Land and Schocket, 'New Approaches to the Founding of the Sierra Leone Colony, 1786-1808'.

122. Marc-William Palen, 'Adam Smith as Advocate of Empire, c. 1870-1932', Historical Journal 57, no. 1 (March 2014): 179-98. esp. 183.

123. For the Revolution, see Smith, 'Food Rioters and the American Revolution', 24. For the 1800s, see Alfred E. Eckes, Jr., Opening America's Market: U.S. Foreign Trade Policy since 1776 (Chapel Hill: University of North Carolina Press, 1995), 26; Marc- 
William Palen, 'Foreign Relations in the Gilded Age: A British Free-Trade Conspiracy?', Diplomatic History 37, no. 2 (Apr. 2013): 217-47, esp. 219, 247.

124. 27 Dec. 1800 , f. 3, CO 270/10, TNA.

125. Wallace Brown, 'The Black Loyalists in Sierra Leone', 122; Fyfe, A History of Sierra Leone, 97; David Northrup, 'Becoming African: Identify Formation among Liberated Slaves in Nineteenth-Century Sierra Leone', Slavery \& Abolition 27, no. 1 (Aug. 2006): 1-21; David Lambert, 'Sierra Leone and Other Sites in the War of Representation over Slavery', History Workshop Journal 64, no. 1 (Autumn 2007): 103-32.

\section{Notes on contributor}

Rachel B. Herrmann is in the Department of History, University of Southampton, Southampton SO17 1BF, UK. Email: r.b.herrmann@soton.ac.uk 